〔目的〕スポーツ障害についての検診車による骨撮影を行ったの でその有用性について報告する。

〔まとめ〕検診車 (間接撮影)においても，骨関節撮影山充分に可 能であり, 腰椎の分離や肘の関節変化などをよく表現し得た。

しかし, 腰椎は, 撮影技術的側面から考元ると被写体厚の厚い部分 の撮影のため, 画質や被曝線量の点で充分に検討を加える必要があ る.

間接撮影であるがゅえの被嚗線量の増加や体位による画質の変化 （ホトタイマーの受光部と被写体との位置関係による変化）などが考 えられ，今後の検討課題と考えられた．また，マニュアルによる撮影 条件も充分に検討していかなければならない.

14. FCR システムの一部を利用した受付情報管理システム

佐賀県立病院好生館

○田浦 勤・吉富正裕・三浦·泰

ID カード畫き込み装置 (ICW) に90MB ハードディスク・ラベル専 用プリンタなどの機器を追加し, 次のような受付業務と集計業務を行 ラソフトを開発した.

受付時, 患者情報登録とフィルムラベル印刷扔よび ID カード発行 が同時に行える. 登録济み患者情報は僢時に呼び出し利用できる. 撮 影後，撮影法・フィルム数など撮影情報を登録すると，一覧表示や検 索が迅速に出来る. 集計を自動化, 件数・フィルム数など日次・月次・ 年次の集計リポート 8 種扔よび照射録一覽表を印刷。

結果注受付業務の手書作業が大幅に隇少し，省力化できた。また， 検索・集計が迅速かつ正確となり，待ち時間短縮など患者サービスに もつながる成果を得た.

\section{5. 不均等被嚗測定の有用性について}

熊本大学医学部附属病院中央放射線部 ○白川裕一・高田卓雄・肥合康弘 松下元-.-

〔目的〕医療の現場において不均等被曝の測定は重要な問題であ る.われわれは, プロテクターを着用する事によって起こる不均等被 曝について測定・検討を行った。

〔方法〕プロテクターを着用して業務を行う放射線技師のプロテ クター下の胸部にフィルムバッジを，プロテクター外の頝部に TLD を装着して，1 1 月月単位延べ30名の被懪線量を測定した。

〔結果〕TLD の測定值はフィルムバッジの測定值より平均 3.9 倍 值が大きく, 二つの個人被嚗線量計で求めた実効線量当量は従来の胸 部に着用したフィルムバッジのみから求めた值より約 2 倍も数值が 大きく不均等被曝測定の有用性が証明できた。

16. パソコンを用いた胸部断層撮影の撮影条件記録システム

福岡大学病院放射線部

○中牟田隆司・平田 巧・吉川治雄 稲冨孝治・上村忠久・満永維明 山崎三男

胸部断層撮影は定期的に撮影することが多く,同じ患者を何度も撮 影することも少なくない. しかし，胸部断層撮影条件は個人差が大き く，再現性のある像を得るのは難しい。そこでパソコンを利用して， 個人情報を管理するデーターベースプログラムを作成し, 短時間で前 回までの撮影部位および条件の検索ができるようにした。

この結果, 登録済みの撮影については, 撮影条件不良による再撮影 はなくなり，患者の被ばく線量減少と作業の効率化が可能となった。 今後は, 表示方法の検討, 入力をさらに簡素化するなどの工夫をして 使い易いプログラムにして行くつもりである。

\section{座長集約}

撮影・管理のセッションは 4 題の発表が行われた。

演題13は，青年期に抽けるスポーツ障害 (时関節や腰椎) に対し検 診車の透視間接撮影装置による骨撮影の有用性についての報告であ った，対象者は高校生野球部員で123名全員に対しアンケート調查扔 よび腰椎 4 方向, 肘関節 2 方向の撮影を行ない検討した。結果, 検診 車による骨間接撮影にて,関節の変化や腰椎分離などよく表現し検唁 として充分な情報をもたらし有用であるとの報告であった。今回の発 表の中で, 残念であったのは，青年期に対するX線撮影において，被 爆線量の測定が行われていなかった。さらに技術的な面からみた撮影 に対する検討が行われていなかった。
演題14は FCR 装置の一部である ID カード書き込み装置 (ICW) を 利用して, 受付情報管理システムを構築したものであった。 ID カード 作成時の患者基本情報入力を利用し,フィルムラベルの作成や撮影件 数やフィルム枚数などの撮影情報も同時に管理できるものであった。 ID カード発行だけの目的に ICW を使用せず，機能を拡大し，OA 機 器を導入せずに受付業務や集計業務の省力化ができる良い方法であ った. 将来的には, 病院ホストコンピュータとのオンラインによる患 者情報の入力化撮影装置から撮影情報の自動入力など期待したい

演題15は法改正によりフィルムバッチの着用が異なったが, 特に最 大被懪量部位での測定について有用であるかどうかの検討を行った ものであった、フィルムバッチと TLDで測定を行った結果, ポー夕 ブル撮影の業務では従来の胸部に乩けるフィルムバッチ(プロテクタ 一下）の值と甲状腺部分に扔ける TLDの值に差が大きかったとの報 告であった. 今回の検討に扔いて, 測定群の分け方が業務内容と測定 結果を分析するには十分でなかったと感じる. 測定群どうしで重複す る盖務内容になっていたりしていた.十分な測定デー夕量ではなかっ たようで，信頼度にやや問題が残った。この研究内容は，診療放射線 業務に従事する者としては興味深いものであり, 是非十分な測定なら びに検討をしていただき，再度報告していただきたい。

演題16はパソコンを用いて胸部断層撮影の条件を登録して撮影時 に検索し，撮影条件の安定化を図ろうとするものであった。市販のパ ソコンで Basic 言語を用いてプログラムを作成し行ったもので,この システムの利用で再現性の良い胸部断層写真が得られるようになっ たとの結果だった。胸部断層撮影は, 病状など個人間のばらつきが多 く, 再現性のある撮影を維持するのがむずかしい分野であるが，パソ コンによる撮影条件の管理システムで効率良く, 再現性のある撮影が できたという良い方法と思う.これからは, さらに表示方法, 入力効 率など検討を加えてわれわれの使いやすいシステムにしていただき たい.

最後に発表された演者のみなさんの益々の御研鑚をお祈りし, 次回 発表につないでいただきたいと思います。 [CT]

座長 冨吉 司（鹿児島大学医学部附属病院）

17. 断層厚さの測定（その 5 エアーギャップ法）

九州大学医学部附属病院放射線部 馬場 仁・廣渡 諭・西村弘幸 小川和久

CT の断層厚さの測定は，アルミ傾斜板法が一般的であるが $2 \mathrm{~mm}$ 以下のスライスになると精度が悪い. そこで，2本のアクリル円柱棒 の間に笁気の間隙 (エアーギャップ) を作り，これを少しずつ移動し 断層面の感度分布を求め, その半值幅を断層厚さとする方法を考案し た。この方法を使用することにより， $2 \mathrm{~mm}$ はもちろん，現在ではあ まり測定されていなかった $1 \mathrm{~mm} も$ 精度良く測定できた。

18. CT 装置の機能評価

\section{九州大学医学部附属病院放射線部}

○広渡 諭・馬場 仁・西村弘幸

最近の CT 装置は, スキャン時間や画像再構成時間などの基本性能 の高速化が図られている。しかし，その他後述する諸機能については 考慮されていない.そこで，今回当施設に三台目の高速 CT が設置さ れたのを機に次の五項目について検討を行ったので報告する。

(1)撮像機能 (2)画像めくり機能 (3) ROI 機能 (4)自動表示機能 (5)ソ一ト機能

この中で撮像機能の自動化はすでに報告されているように大きく 検查スループットに関与しており絶対不可欠と考えている.また，そ の他全ての機能は各装置数秒とわずかな時間差ではあるが,一日に換 算すれば大きく使用頻度の多い機能は高速化の必要がある。

19. ヘリカルスキャンにおける識別能について

$$
\begin{aligned}
& \text { 九州大学医学部附属病院 } \\
& \text { O西村弘幸・馬場 仁・広渡 諭 } \\
& \text { 小川和久 }
\end{aligned}
$$

ヘリカルスキャンと従来スキャンの識別能の相違に関して,スライ スプロフィール形状および実效スライス厚について，またスライス 厚, 演台移動速度, 被検体の大きさ, 画像切り出し位㯰の変化につい て，各々検討した。 
結果として,ヘリカルスキャンにおいて，各々のスライス厚は寝台 移動速度により変化し，その実効厚に対する被検体の大きさの関係加 ら，その識別能は従来スキャンより劣る場合がある. 任意に画像再構 成位置を選択できることにより，従来スキャンによる検査法に比べ， より確実に被検体を識別できる可能性がある.

\section{座長集約}

演題17は, CT のスライス厚の評価法として, 従来行われていたア ルミ傾斜板法, パーシャルボりューム法より精度が良いエアーギャッ プ法を考案し報告した。この方法は, 従来の測定法では誤差の多い 1 〜 $2 \mathrm{~mm}$ の薄いスライス厚の評洒に有用であり, $1 \mathrm{~mm}$ 厚さが測定可 能とした。また，エアーギャップ法は補正関数によるスライス厚さも 変化しないので良い評価法であると報告した。今後の検討課題として は，実験材料のアクリル円柱の凹凸があり，円柱作成の精度が厚さ測 定精度に影響すると述べている。

質問 アルミ傾斜板法, パーシャルボリューム法扔よびエアーギャ ップ法の長所, 短所を教えて下さい

答 アルミ傾斜板法は $2 \mathrm{~mm}$ 以下の厚さ測定で誤差が大きい.しか し, 経時的変化を測定するには簡便で良い方法である。 パーシャルボ リューム法は差分をとるために誤差が生じやすい.エアーギャップ法 は従来法より精度が向上した測定法である。

演題18 $\mathrm{CT}$ 装置の機能証洒と題し, 装置の操作性, 撮像機能など の周辺機能について 3 機種を此較し, その重要性を評価して報告し た、今回は以下の項目についてまとめている.1，画像めくり機能は機 種間の差は $2 \sim 3$ 秒と少ないと思われるが，一日400枚画像めくりを 行うと 20 分活どの差となり患者の 1 人の検査時間に匹敵するほどに なるので速いほど良い.2. ソ一ト機能としては, 部分ソート機能が必 要と強調した. 3 . 自動撮像機能は,スキャン中にも撮像可能な機構が 必要である. 4．自動表示機能と ROI 機能は，マウス入力よりワンタ ッチボタンスカが操作性が良い. CT 検查は，全体のスループット向 上のためには, 周辺の操作性も重要でありユーザ側からメーカ側へ多 くの要求が必要であるとまとめた。

助言 森山 (九州大学) 装置の設計者側とユーザ側で装置性能, 操 作性の考え方に差が生じている.人間工学的にはどのような操作性が 必要かをユーザとして研究し要求することが大事である.

演題19は, 識別能についてへリカルスキャンと従来のスキャン法と を比較して報告した。へリカルスキャンでは, 寝台移動速度とスライ ス厚抢よびコントラストとの関係が問題となっているが, スライス厚 さについて従来の評洒法では問題あるとし，その解決策については今 後の検討課題であるとした.

質問 中野（産業医大）識別能という表現をしているが，分解能と はどう違うのか。

答 ヘリカルスキャンの場合, 切り出し位置に差があっても, 従来 スキャン法より被写体の識別が可能であり，識別しやすいという意味 で識別能と表現した。

[MR〕

20. POMP 法の活用と SPGR 法 MRA について

座長 中野 努（産業医科大学病院）

琉球大学医学部附属病院放射線部

○島崎順之・比嘉 靖・新坦勝夫

島袋治良・真栄城守侯

当院では91年 6 月より GE 社製 Signa Advantage $1.5 \mathrm{~T}$ が稼動 している。このシステムの POMP (Phase Offset Multi Planar) 法 の紹介と，SPGR 法と GRASS 法, 特にMRA について比較検討し た.POMP 法は, 二つのスライスを同時に励磁できる混合パルスを使 用することによって，TR 間でのスライス数は 2 倍となるため，通常 法での検查に扔いては時間短縮となる。当院では頭部, 䅡部, 骨盤, 股関節などの Axial T1 撮像に使用している．また SPGR 法 TOF Angio ではフリップ角20〜30度が良く，Grass と比較して SPGR の ほうが少しコントラストが高かった。

21.POMP 法の頭部での有用性について

健康保険諫早総合病院放射線部

○氏原健吾・百田裕三・井上裕之

本田勝己・江崎浩二

〔目的〕 POMP 法は, 同一TR T゙ 2 倍, 3 倍のスライス枚数が得ら
れる新しいシーケンスである,従来のスライス枚数を増倍させること で検查時間の短縮を図ることができたので報告する。

〔使用装置〕 MR-Vectra 0.5T（横河メディカルシステム）

〔結果〕 POMP 法はTR 当たりのスライス枚数を，2 倍あるいは 3倍にできるため, より短い TRでの撮影が可能であり，時間短縮と T1 コントラスト向上につながる.したがって, Short-TR, Short-TE のパルスシーケンスで頭部全域をカバーしたい時に極めて有用であ る.

\section{Enhanced Snap Shot Angiogram}

$$
\begin{gathered}
\text { 鹿児島大学医学部附属病院放射線部 } \\
\text { ○小林保浩・福島 昇・池田 睦 } \\
\text { 下野哲勇 }
\end{gathered}
$$

鹿児島大学医学部附属病院放射線科 池田耕治

〔目的〕病変の皿行動態にともなった経時的な変化ちよび占拠部 位の全体像の描出のため新しい方法を試みた.

[方法〕病変部位・大きさなどによりスライス厚，スライス数を設 定する. その設定条件で Gd-DTPA 注入前・後に, Turbo-Flash 法 による数スライスずつの連続高速撮像を行う.次に同じ時間帯の数画 像ずつを M.I.P. (maximum intensity projection) 法にて処理をし た。その処理画像の 1 画像毎あるいは，シネイメージとして病変部の 観察を行った.

〔結果〕今回の方法は, 血管性病変および腫瘍性病変の血行動態に よる経時的な評価ならびに病変占拠部位の評価に有用であった。

\section{座長集約}

MR のセッションは 3 題の研究発表があった. 2 題はシーケンスの 特性, 他の 1 題は臨床応用に関する演題である.

演題20は新しく開発されたシーケンス POMP (phase offset multi planar) 法と SPGR（spoiled grass）法の特性に関するものである。 POMP 法は從来法に比較して 2 倍また活 3 倍の撮像枚数が得られる。 これによって，TR 時間の短縮や撮影可能な枚数が少ない short SE での一回当たりのスキャンボリュームを増やし，検査のスループット の向上を図っていた. また, grass 法と SPGR の angiography での比 較検討を行い，SPGR のほうがコントラストの点で優れていること を報告した。

質問 座長 従来法に比較して POMP 法はコントラストの低下 がみられると述べているが，S/N のほうはどうか.

答 $\mathrm{S} / \mathrm{N}$ は測定していない.

質問 船間（熊本大学）従来法の一回収集と POMP 法の 2 回収集 の画像の画質はどちらが良いか.

答 POMP 法の 2 回収集のほうが良い

演題 21 は演題20と同様 POMPに関する発表であるが，演題20が $1.5 \mathrm{~T}$ の装置であるのに対し，演題21は $0.5 \mathrm{~T}$ の装置でのものである. このため同じ POMP を用いても，演題 20 が short SE 撮像時のスル ープットの向上を主眼にしているのに対し，この演題では T1 強調画 像のコントラストの向上に主眼が向けられていた. 中磁場の装置では 高磁場のそれに比較して短い TR 時間でないと十分な T1 コントラ ストが得られない.このため, POMP 法は画質の向上が得られる中磁 場の装置でより大きなメリットがあるものと思う。

演題22 は超高速撮像法 (Turbo flash) の臨床応用に関する演題であ る. Turbo flash で Gd-DTPA 造影前後の撮像を行い, 後処理したも のをシネモードで観察するものである.これによって，動脈瘤のよう に通常の MRA では欠損像となる部分も血流変化に影響されずに描 出されていた。この手技では血管性病変と腫瘍性病変のいずれにも有 用に思われる.臨床のビデオを紹介していたが，これまでのどの検査 方法を用いても見ることのできない映像を見せられ大変與味深加っ た. 今後さらに技術的な検討を重ね, 検查手技を確立されることを望 みたい。

質問 肥合（熊本大学） Turbo flashのタイプは。

答 $180^{\circ}$ パルスをかけるタイプのものである。

質問 船間 (熊本大学) coronal で撮像しているが, axial で撮像し て画像再構成したものと比較した場合どうか。

答 血流をとらえる必要があるため, 何枚も撮像の必要な axial の 方向では不可能である. 